\title{
New records of desmids from Ropar wetland (a Ramsar Site) of Punjab, India
}

\author{
Komal $^{1}$, J.I.S. Khattar ${ }^{2}$, D.P. Singh ${ }^{2} \&$ Yadvinder Singh ${ }^{1^{*}}$ \\ ${ }^{1}$ Department of Botany and Environmental Science, Sri Guru Granth Sahib World University, Fatehgarh Sahib 140 406, Punjab, India \\ ${ }^{2}$ Department of Botany, Punjabi University, Patiala 147002, Punjab, India \\ *Email: yadbotany@gmail.com
}

\section{ARTICLE HISTORY}

Received: 24 April 2021

Accepted: 21 July 2021

Available online

Version 1: 24 August 2021

Version 2: 05 February 2022

\section{KEYWORDS}

Closteriaceae

desmid

India

Punjab

Ropar wetland

\section{ABSTRACT}

This study deals with exploration of freshwater desmids for the first time from Ropar wetland (Ramsar site) of Punjab (India) to assess their taxonomic aspects and bio-geographical distribution. During this study, samples of planktonic, epiphytic and epilithic desmids were collected from littoral zone and were observed under light microscope for their morphometric characteristics based identification. Total 21 desmids species belonging to 4 genera of 2 families (Closteriaceae and Desmidiaceae) were identified from the collected samples. Among them, Cosmarium with 11 species ( $C$. awadhense, $C$. bioculatum, C. trilobatum, C. divergens, C. granatum, C. moniliforme, C. nitidulum, C. subtumidum, C. reniforme, $C$. undulatum and $C$. obtusatum) was found to be most abundant followed by Closterium with 7 species (C. acerosum, C. dianae, C. incurvum, C. leibleinii, C. lunula, C. pritchardianum and C. aciculare), Euastrum with 2 species (E. spinulosum and E. platycerum) and Staurastrum with 1 species (S. crenulatum). The geographic distribution of identified desmid taxa in India has been also recorded. All the desmid taxa identified during this study are new record for the Punjab state of India. The results of this study provide significant baseline data for the future taxonomic and ecological studies from the similar habitats.

\section{Introduction}

Globally, wetlands are recognized as one of the most biologically diverse and unique habitats for various plant and animal species (1). Wetlands are also considered as important aquatic environments that provides valuable ecosystem services by supporting high rates of primary production $(1,2)$. In spite of their importance, most of the world's wetlands are under threat due to the increased human interference including deforestation, change in land use practices, domestic and industrial pollution etc. in their catchment areas and watershed $(1,3)$. As a result the hydrology, hydraulic patterns and geomorphology of most of the wetlands have been influenced that directly impact their biodiversity and other ecosystem services $(1,2)$. At the same time, it has been recognized that proper protective and conservation efforts have not been implemented for such important ecosystems due to lack of knowledge about their ecological values and benefits $(2,5)$ Therefore, the assessment of biodiversity and its role becomes important for the better understanding of services and functions of wetlands $(6,7)$. Algae, as main primary producers, play important role in functions of wetlands and can be the key indicators for their ecological conditions (2). Algae often are conspicuous feature of both estuarine and freshwater wetlands throughout the world (2). On the basis of cell structure algae are mainly two types: prokaryotic (Blue green algae) and eukaryotic (all other algal forms including desmids). Desmids are microscopic, unicellular, eukaryotic organism belong to class Zygnematophyceae (Phylum Charophyta) of algae (810). The cells of majority of the desmids taxa are transversally curved by constriction (sinus) into two symmetrical semi-cells connected by an isthmus $(8,9)$. The desmids taxa consist symmetrical semi cells and isthmus with pores are known as true desmids (placoderm), whereas smooth walled taxa, without pores and a median constriction are termed as false desmids (saccoderm) $(11,12)$. Desmids are vulnerable groups of aquatic organisms due to their sensitivity to the fluctuations in the environment. Thus, desmids are increasingly used as bioindicator for the monitoring and management of aquatic ecosystems (11, 13-15). Due to this, the taxonomic and floristic explorations of these organisms become important to understand their complex association with environment. 
The diversity of desmids from different regions of the world has been explored by many workers (16-27). In India, many studies have been reported from different parts, like from Dehradun (28), Ladakh (29, 30), Uttar Pradesh (31), Karnataka (32, 33), Maharashtra (12, 14, 34-39), Western Himalayas (40), Himachal Pradesh (41), Eastern Himalaya (42), West Bengal (43) etc. Although, algal diversity from different water bodies of Punjab has been explored by various workers (44-49) but, according to available literature, detailed taxonomic studies on desmids are not been carried out till date leading to a gap in knowledge about the diversity of this important group of algae. Keeping this situation in mind, present study was undertaken to explore the desmids flora from Ropar Wetland of Punjab for the first time.

\section{Materials and Methods}

\section{Study Area}

Ropar wetland, manmade fresh water wetland, situated on river Sutlej at $31^{\circ} 01^{\prime} \mathrm{N}$ latitude and $76^{\circ} 30^{\prime} \mathrm{E}$ longitude in the Shivalik foothills covering an area of $13.65 \mathrm{sq} . \mathrm{km}$ (Fig. 1). This wetland came in to existence in 1952 after the construction of water barrage on river Sutlej at Ropar (Rupnagar district, Punjab). The main reason behind constructing this wetland was to store and divert water through canals for various purposes like irrigation, industrial and drinking water supply $(50,51)$. This was considered as Ramsar site in year 2002, due to its vital role in providing habitat to number of threatened and endangered species of plants and animals (50). This area falls under semiarid zone and relatively less warm region of Punjab and it receives mean annual rainfall of $1518 \mathrm{~mm}$ (52). This wetland is very significant from ecological, economic and social heritage point of view. It also serves as significant staging and latent ground for migratory water fowl. The major threats for this wetland are weed invasion by Parthenium and Lantana, siltation, water pollution through anthropogenic activities and grazing etc. (53, 54). Previous studies from this wetland have reported the declining status of its water quality and ecological conditions (51-54). These water quality conditions may causes serious alterations in various abiotic and biotic components of this wetlands. As desmids are considered as good indicator and are sensitive to the fluctuations in water chemistry of any freshwater ecosystem. Thus, it becomes important to evaluate the diversity of desmids from this wetland that may be helpful in future for formulation of any management plan/program for its conservation and rehabilitation.

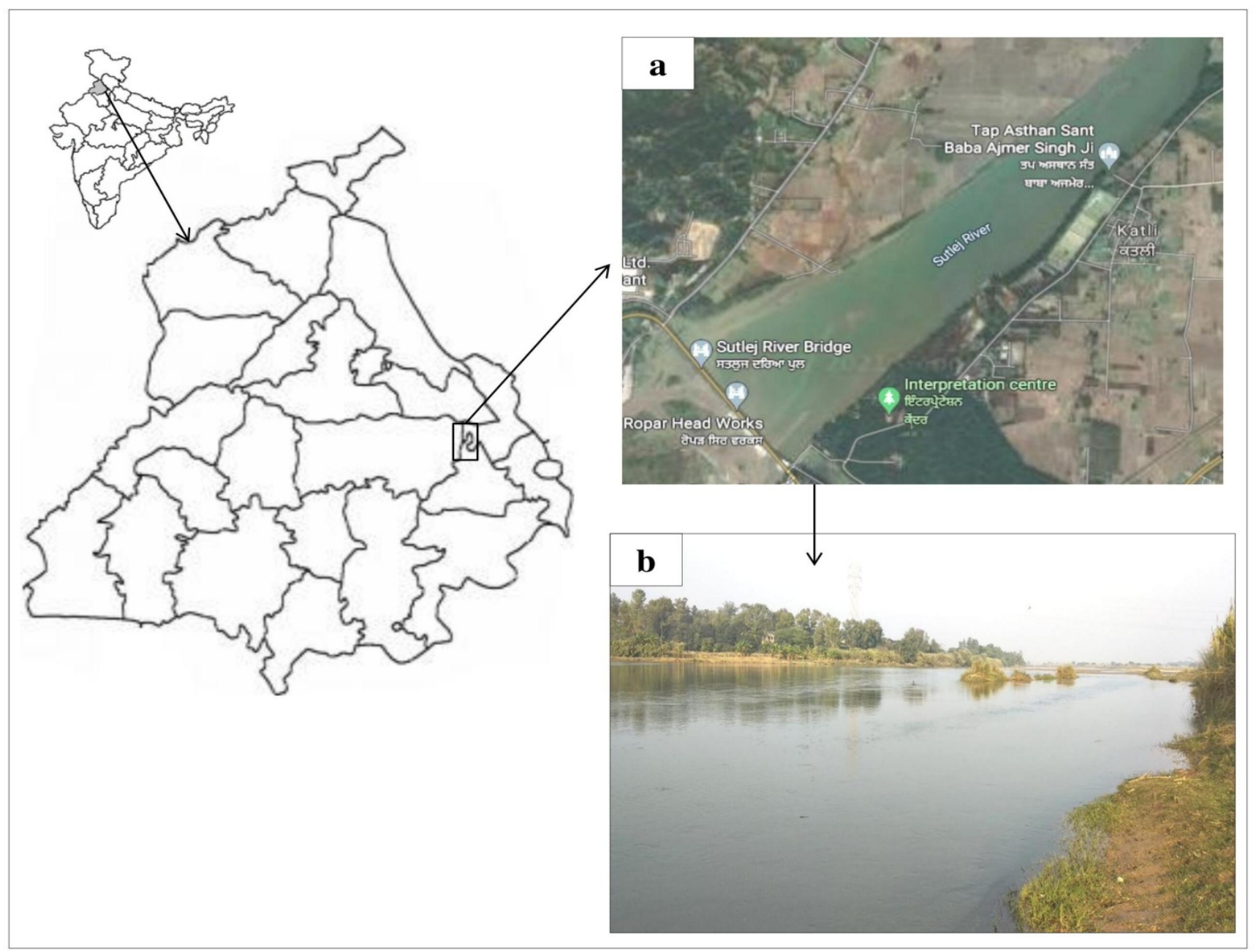

Fig. 1. Map showing Ropar Wetland of Punjab, India (a): Satellite view (Source: www.maps.google.com), (b): Field photograph at the time of sample collection. 


\section{Sample Collection and Identification}

Samples of planktonic, epiphytic and epilithic desmids were collected from littoral zone of study area (Fig. 2). Collected samples were preserved in formalin solution (4\%) in wide mouth glass bottles and for further analysis were brought to the

\section{Results}

In the present study, a total of 21 desmids taxa belonging to 4 genera (Closterium, Cosmarium, Euastrum and Staurastrum) of 2 families (Closteriaceae and Desmidiaceae) have been reported
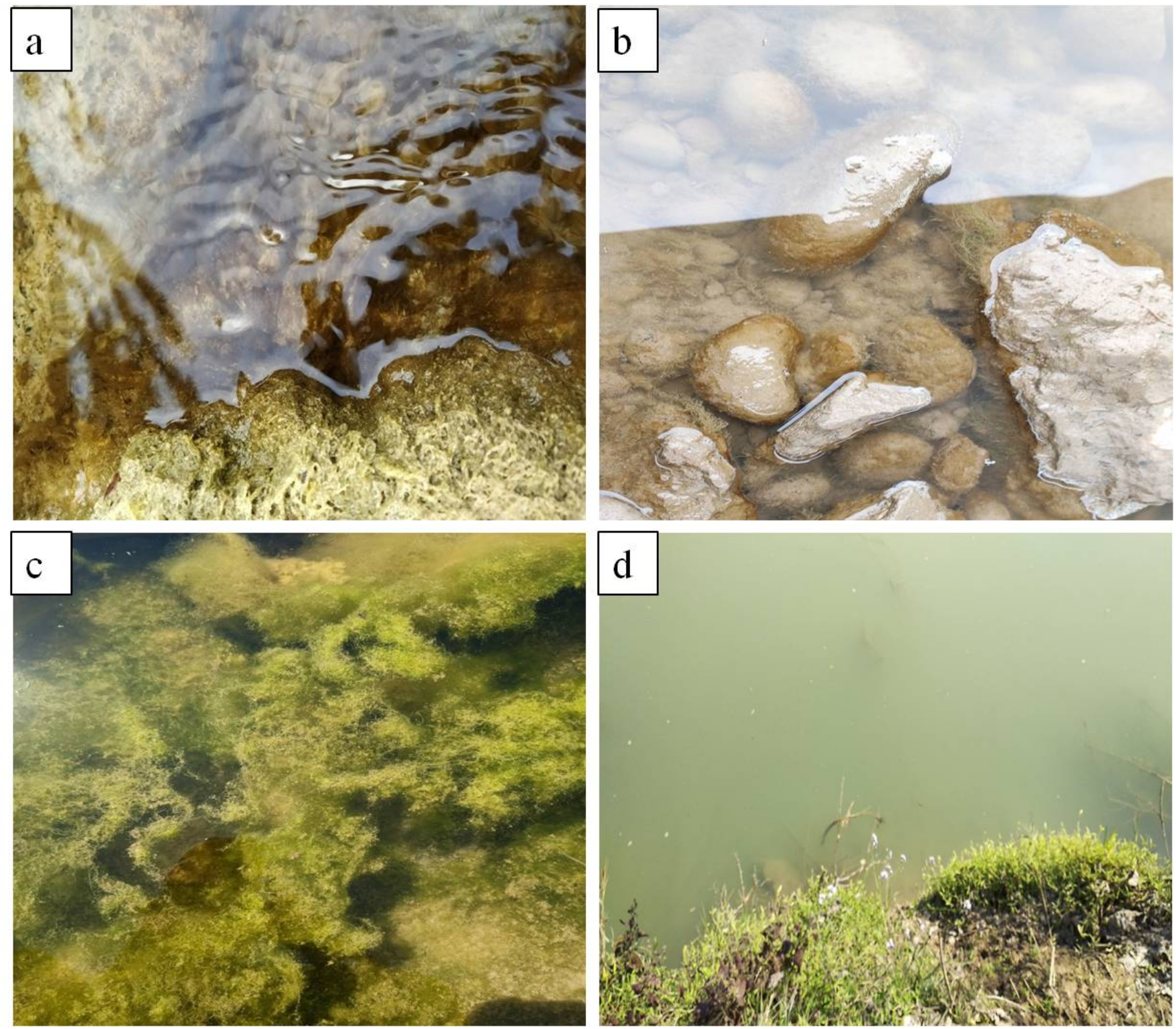

Fig. 2. Field photographs showing different algal habitat in littoral zone of the study area.

laboratory. The voucher specimens of collected samples were assigned with herbarium number (WUA) of Sri Guru Granth Sahib World University, Fatehgarh Sahib (Punjab). The temperature and $\mathrm{pH}$ of water were recorded on the spot with digital thermometer (Perfit, India) and digital $\mathrm{pH}$ meter (Hanna Instruments, India) at the time of sampling. For the identification of collected material, temporary slides were prepared by mounting sample in Glycerin to study the morphometeric characteristics using light microscope (Olympus CH20i). The species identification was done following standard literatures (55-61) and the geographic distribution of identified desmids taxa was analyzed from referred literature. for the first time from Ropar Wetland, Punjab. The microphotographs of studied desmid taxa are given in Fig. 3 \& Fig. 4.

The identification key and detailed taxonomic descriptions of identified taxa are given below:

1. Cell solitary, small to large $.2,3,5$

1. Cell solitary .4

2. Straight, curved, elongate-cylindric to elongatefusiform, tapering at ends, ends acute, rounded or truncate, chloroplast two with numerous pyrenoids. Closterium....6

3. Semicells circular, subcircular, elliptic, reniform, pyramidate, quadrate in apical view, shallow to deep constriction, cell wall smooth, ornamented 

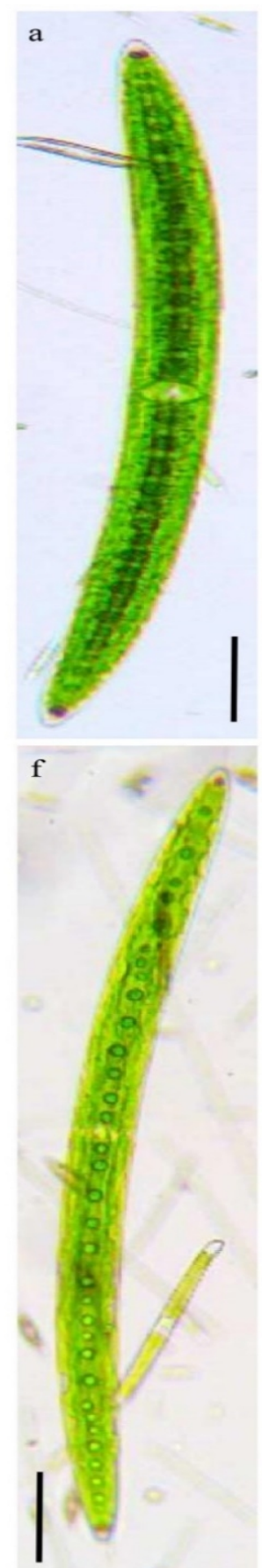

b

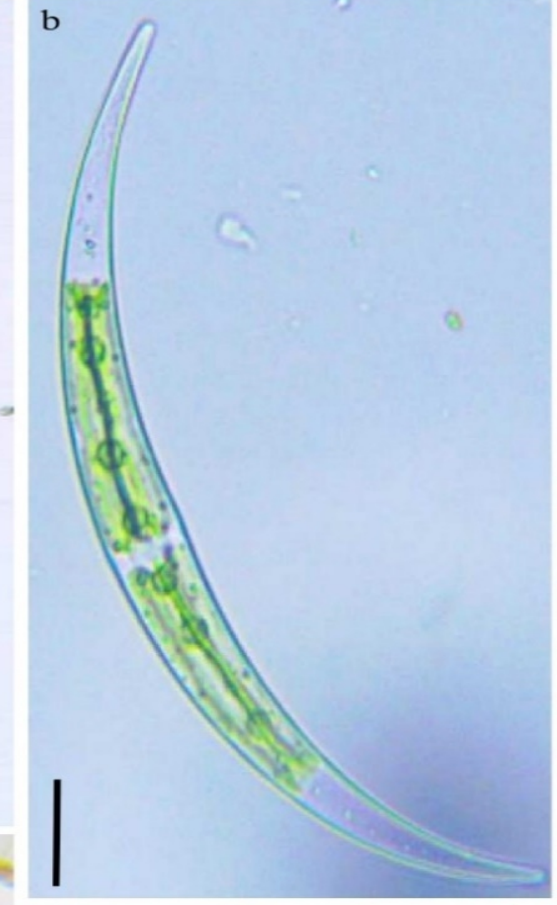

h
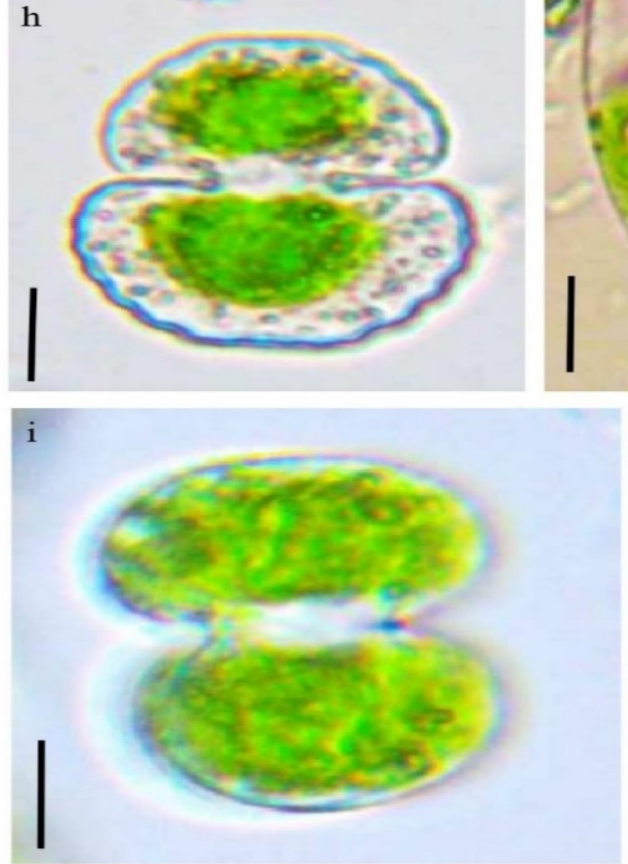

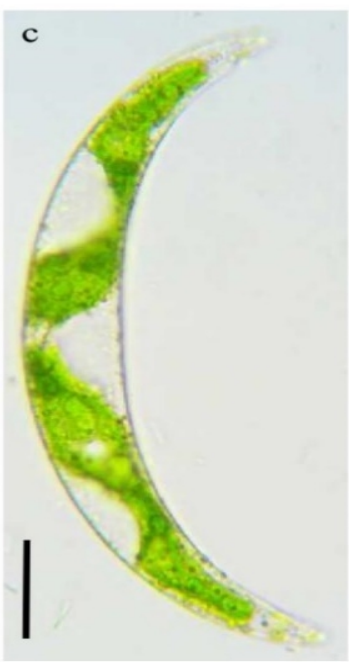

e

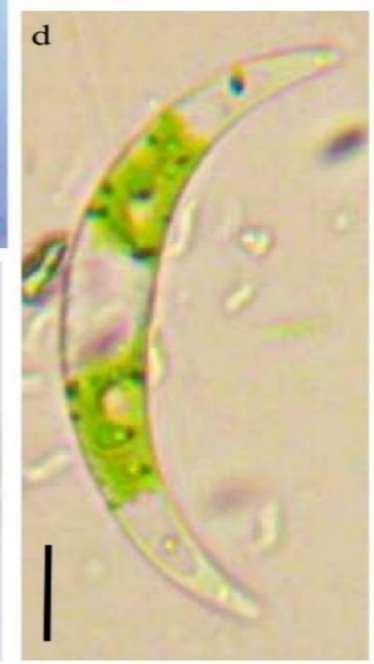

j

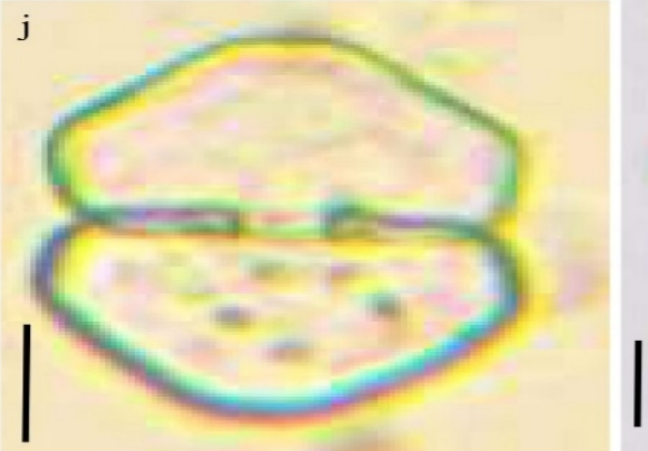

Fig. 3. Micro-photograph of identified desmid taxa from study area. (a): Closterium acerosum Ehrenberg ex Ralfs;(b): Closterium dianae Ehrenberg ex Ralfs; (c): Closterium incurvum Brébisson; (d): Closterium leibleinii Kützing ex Ralfs; (e): Closterium lunula (Muell.) Nitzsch; (f): Closterium pritchardianum W. Archer; (g): Closterium aciculare T. West; (h): Cosmarium awadhense B. N. Prasad \& R. K. Mehrotra; (i): Cosmarium bioculatum Brébisson ex Ralfs; (j): Cosmarium trilobatum Reinsch. (Scale bar = $20 \mu \mathrm{m})$.

with granules, each semicell with one to more chloroplast. Cosmarium...12

4. Semicells with apical and lateral lobes, smooth cell wall with ornamentations. Euastrum...29

5. Each semi-cell with hollow processes deep median constriction, processes with two or more outmost spinules. Staurastrum...33

6. Cells narrowly fusiform. 7

6. Cells lunated. .8

7. Apices rounded and truncate...Closterium acerosum 8a. Apices subacute.

Closterium dianae

8 b. Apices pointed and rounded...Closterium incurvum

9. Cells strongly curved. . .10

9. Cells slightly curved

9. Cells large and nearly straight.

10a. Apices nearly recurved. Closterium leibleinii 10b. Apices attenuate .Closterium aciculare 

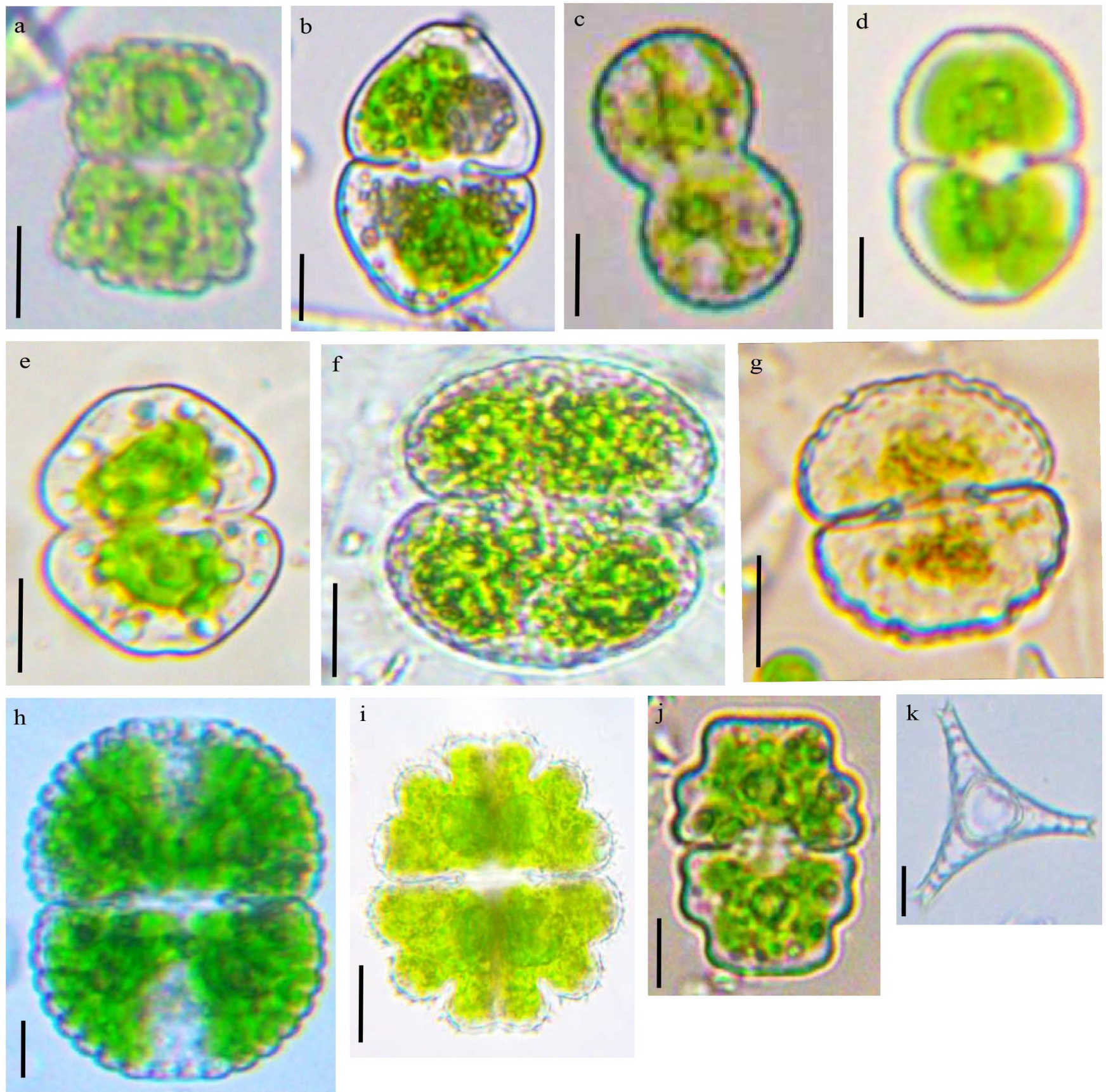

Fig. 4. Micro-photograph of identified desmid taxa from study area. (a): Cosmarium divergens Krieger; (b): Cosmarium granatum Brébisson ex Ralfs; (c): Cosmarium moniliforme Ralfs; (d): Cosmarium nitidulum De Notaris; (e): Cosmarium subtumidum Nordstedt; (f): Cosmarium reniforme (Ralfs) W. Archer; (g): Cosmarium undulatum Corda ex Ralfs; (h): Cosmarium obtusatum (Schmidle) Schmidle; (i): Euastrum spinulosum Delponte; (j): Euastrum platycerum Reinsch; (k): Staurastrum crenulatum (Nägeli) Delponte. (Scale bar= $20 \mu \mathrm{m}$ ).

11a. Apices truncate and faintly recurved. Closterium pritchardianum

11b. Cell reduced to slightly truncate apices .Closterium lunula

12. Cells small 13,15

12. Cells longer than broad

13. Profound constriction with narrowly linear sinus

13. Little median deep constriction with widely open acute sinus.
14. Median deep constriction with narrowly linear sinus 16,18

14. Closed and deep sinus. .17

15. Deep constriction with narrow sinus 18,19

16. Semi-cells semicircular.

Cosmarium awadhense

16. Semi-cells nearly elliptic

Cosmarium bioculatum

17. Semi-cells circular.

Cosmarium moniliforme

17. Semi-cells elliptical. 
18. Semi-cells truncate-sub semicircular .21

18. Semi-cells pyramid-semicircular .Cosmarium subtumidum

19. Semi-cells sub-semicircular with 6-7 undulations ... .21

20. Coarsely scrobiculated cell wall. Cosmarium trilobatum

20. Cell wall finely punctuate. Cosmarium divergens

21a. Punctate cell wall. Cosmarium nitidulum

21b. Cell wall smooth Cosmarium undulatum

22. Cells medium sized. $.23,24$

23. Deep constriction with closed sinus .25

23. Deep constriction with narrow to linear sinus 24. Middle constriction with linear sinus .25

24.Deep constriction with linear sinus .26

25. Semi-cells trapezoid. .26

25. Semi-cells reniform .27

26.Semi-cells sub-semicircular .27

26. Semi-cells sub-rhombic to elliptic. .28

27. Punctate cell wall Cosmarium granatum

27. Granulate cell wall Cosmarium reniforme

28. Smooth to slightly punctate cell wall Cosmarium obtusatum

28. Finely punctate cell wall.......Cosmarium divergens

29. Cells small.............................................................30

29. Cells medium. .30

30. Deep constriction with narrow sinus..... .31

30. Sinus slightly open .31

31. Semi cells with 5 lobed rounded angles. .32

31. Semi cell with circular patch of granules .Euastrum platycerum

32. Cell wall with short spines

Euastrum spinulosum

33. Cells with short and slightly divergent processes, semi-cells oval or sub-fusiform, shallow median constriction cell wall crenate to denticulate Staurastrum crenulatum

\section{Closterium acerosum}

Ehrenberg ex Ralfs 1848: 164, pl. XXVII [27]: Fig. 2 a, b, d-e.

Narrowly fusiform cells, 160-175 $\mu$ m long, $13 \mu \mathrm{m}$ wide; outer margin curved with gradually tapering to narrow inner margin; apices rounded and truncate, 4 $\mu \mathrm{m}$ broad; cell wall smooth, without any colour, with median girdle; chloroplast without ridges and having 3-5 pyrenoids in a medium series (Fig. 3, a).

Collection no.: WUA 18, WUA 34, WUA 14 and WUA 43.
Ecological notes: From the water squished from other algal samples. $\mathrm{pH} 7.7$, Temp. $21^{\circ} \mathrm{C}$.

Indian distribution: Kerala (62), Western Himalaya (40), Tamil Nadu (63); Maharashtra (12, 39); Jodhpur, Rajasthan (64, 65), Madhya Pradesh (66).

Closterium dianae Ehrenberg ex Ralfs 1848: 168, figs 5a, 5c; pl. XXVIII [28].

Lunated cell, 160-188.6 $\mu \mathrm{m}$ long and $12.5 \mu \mathrm{m}$ wide; a strongly curved outer margin, inner margin slightly swollen, with subacute apices; Smooth cell wall; chloroplast having 6-8 pyrenoids in a row (Fig. 3, b).

Collection no.: WUA 22, WUA 26, WUA 47 and WUA 31.

Ecological notes: In association with green algal filaments growing attached on stones. $\mathrm{pH}$ 7.8, Temp. $24{ }^{\circ} \mathrm{C}$.

Indian distribution: Manipur (67), Bhopal (68), Maharashtra (9, 39), Madhya Pradesh (66), Arid region, Rajasthan (65).

Closterium incurvum Brébisson 1856: 150, pl. 2: Fig. 47.

Cell lunated, 50-87.5 $\mu \mathrm{m}$ long and 7.5-11.5 $\mu \mathrm{m}$ wide, apex nearly 2.7-2.9 $\mu \mathrm{m}$ wide; convex dorsal margin, concave ventral margin, pointed-rounded poles; smooth, hyaline to brownish cell wall, with or without polar thickening; chloroplast is axial, 3 lamella, 2-5 pyrenoids in median series (Fig. 3, c).

Collection no.: WUA 10, WUA 17 and WUA 43.

Ecological notes: Attached with cyanobacterial filaments. $\mathrm{pH}$ 8, Temp. $23^{\circ} \mathrm{C}$.

Indian distribution: Andaman and Nicobar (28), Eastern Himalayas, Assam (69), Manipur (67), Kerala (70), Karanja, Maharashtra $(9,71)$.

Closterium leibleinii Kützing ex Ralfs 1848: 167, pl. XXVIII [28]: fig. 4 c-h, k-l.

Cell strongly curved, $58 \mu \mathrm{m}$ long and $10.2 \mu \mathrm{m}$ wide; outer margin with 115-120 degrees of arc; middle part inflated and inner margin deeply concave, nearly recurved apices; smooth cell wall; chloroplast having serially arranged numerous pyrenoids in each semi cell (Fig. 3, d).

Collection no.: WUA13, WUA 07 and WUA 09.

Ecological notes: Slimy mass growing benthic near the wetland area. pH 7.9, Temp. $23^{\circ} \mathrm{C}$.

Indian distribution: Madhya Pradesh (72), Andaman and Nicobar (28), Ladakh (30), Western Himalayas (40), Bhopal (68), Maharashtra (8, 39, 71, 73, 75) Rajasthan $(57,58)$.

Closterium lunula Ehrenberg \& Hemprich ex Ralfs 1848: 163, pl. XXVII [27]: Fig. 1.

Large sized cells, nearly straight, about 6 times longer than broad, 200-220 $\mu \mathrm{m}$ long and $30 \mu \mathrm{m}$ wide; outer margin is more convex than inner, cell gradually reduced to slightly truncate apices; smooth cell wall; chloroplast with 5 ridges with numerous scattered pyrenoids (Fig. 3, e).

Collection no.: WUA 37, WUA 26, WUA 37 and WUA 41. 
Ecological notes: Attached with other filamentous algae. $\mathrm{pH} 7.9$, Temp. $23^{\circ} \mathrm{C}$.

Indian distribution: Karnataka (72-74), Western Himalaya (40), Jammu and Kashmir (76), Maharashtra (9, 39, 77), Madhya Pradesh (66).

Closterium pritchardianum W. Archer 1862: 250, pl. XII [12]: Fig. 25-27.

Cell medium sized, nearly 10 times longer than broad, $98 \mu \mathrm{m}$ long and 5-6 $\mu \mathrm{m}$ wide, weakly curved, outer margin with 24-40 degree of arc, inner margin slightly concave; cell gradually narrowed toward apex, apices truncate and faintly recurved; smooth cell wall; chloroplast with 5-6 ridges with and 8-10 rows of pyrenoids (Fig. 3, f).

Collection no.: WUA 19, WUA 07, WUA 18 and WUA 25.

Ecological notes: In association with mosses with mucilaginous mass. $\mathrm{pH}$ 8, Temp. $24^{\circ} \mathrm{C}$.

Indian distribution: Madhya Pradesh (78), Karnataka (79), Goa (80), Andaman and Nicobar (28), Western Himalaya (40), Himachal Pradesh (41), Maharashtra (39).

Closterium aciculare T. West 1860: 153, Fig. 16; pl. VII [7].

Cells slightly curved, 80-90 times longer than wide, 200-230 $\mu \mathrm{m}$ long and 4-6 $\mu \mathrm{m}$ wide; slightly curved in apical region, nearly straight dorsal and ventral margins, attenuated apex with pointed poles; colorless, smooth cell wall; chloroplast axial with serially organized 4-6 pyrenoids in median (Fig. 3, g).

Collection no.: WUA 22, WUA 06 and WUA 14.

Ecological notes: In association with cyanobacterial filaments. $\mathrm{pH} 7.7$, Temp. $21^{\circ} \mathrm{C}$.

Indian distribution: Gujarat (81), Kerala (82), Bihar (83), Maharashtra $(76,84)$.

Cosmarium awadhense B.N.Prasad \& R.K. Mehrotra 1977: 55.

Small cell, a little longer than broad, $28 \mu \mathrm{m}$ long and $24 \mu \mathrm{m}$ wide, $4 \mu \mathrm{m}$ wide isthmus; profound constriction; narrowly linear sinus towards apex and slightly open outwards; semicircular semi cells, truncate apex with more or less straight margin; smooth cell wall; one massive chloroplast in each semi cell (Fig. 3, h).

Collection no.: WUA 05, WUA 59 and WUA 53.

Ecological notes: Attached with Benthic algal samples. pH 8, Temp. $24^{\circ} \mathrm{C}$.

Indian distribution: Andaman and Nicobar (28), Ladakh (30), Western Himalaya (40), Himachal Pradesh (41), Jammu and Kashmir (76), Kerala (70), Maharashtra (39, 85), Maharashtra (12).

Cosmarium bioculatum Brébisson ex Ralfs 1848: 95, pl. XIV [14]: Fig. 5.

Cells slightly longer than broad, $27.5 \mu \mathrm{m}$ long and 25 $\mu \mathrm{m}$ wide, $4.5 \mu \mathrm{m}$ wide isthmus; median deep constriction; little dilated apex with narrowly linear sinus; semi cells nearly elliptic in shape in apical view and subcircular in lateral view, upper margin more convex than the ventral, lateral margins rounded; colorless, smooth cell wall; each semi cell with axile chloroplast having single pyrenoid (Fig. 3, i).

Collection no.: WUA 08, WUA 05 and WUA 24.

Ecological notes: In association with other phytoplanktons. pH 7.9, Temp. $19^{\circ} \mathrm{C}$.

Indian distribution: Maharashtra (8, 39), Karnataka (74), Kolkata (43), Karanja, Maharashtra (9).

Cosmarium trilobatum Reinsch 1866: 118, pl. XXII [22]: Fig. A: II: 1-6.

Cells longer than broad with closed and deep sinus, 27$30 \mu \mathrm{m}$ long and 26-27 $\mu \mathrm{m}$ wide; 5.5-7 $\mu \mathrm{m}$ wide isthmus; Semi cells elliptical shaped with rounded angles, straight to slightly convex sides and slightly concave apex; small inflation present in apical view; coarsely scrobiculated cell wall; each semi cell with axile chloroplast having single pyrenoid (Fig. 3, j).

Collection no.: WUA 59, WUA 56, WUA 14 and WUA 07.

Ecological notes: Brownish mass of wooly substances lodged with pebbles. $\mathrm{pH} 8$, Temp. $22^{\circ} \mathrm{C}$.

Indian distribution: Madhya Pradesh (86), Kerala (87), Gujarat (88).

Cosmarium divergens Krieger 1932: 175, pl. XI [11]: Fig. 20.

Medium sized cells with deep constriction, little longer than broad, 20-25 $\mu \mathrm{m}$ long, and 17-19 $\mu \mathrm{m}$ wide; 15.5 $\mu \mathrm{m}$ wide isthmus; linear sinus; cell wall finely punctuate; semi cells sub-rhombic to elliptic in shape; apex and margins crenate; axile chloroplast (Fig. 4, a).

Collection no.: WUA 57, WUA 24 and WUA 48.

Ecological notes: In association with green filamentous algae. pH 8, Temp. $22^{\circ} \mathrm{C}$.

Indian distribution: Gujarat (88), Maharashtra (8, 75, 89).

Cosmarium granatum Brébisson ex Ralfs 1848: 96, pl. XXXII [32]: Fig. 6.

Cells medium, nearly 1.5 times long as broad, 35-40 $\mu \mathrm{m}$ long and 20-25 $\mu \mathrm{m}$ wide, 5-7 $\mu \mathrm{m}$ wide isthmus; deep constriction; sinus closed; semi cell trapezoid in shape; basal angles rounded; punctate cell wall; each semi cell with axile chloroplast (Fig. 4, b).

Collection no.: WUA 60, WUA 56 and WUA 05.

Ecological notes: Attached to benthic algal samples. $\mathrm{pH}$ 7.8, Temp. $23^{\circ} \mathrm{C}$.

Indian distribution: Maharashtra (8, 39, 75, 90, 91), Uttar Pradesh (31, 92) Assam (93, 94), Jammu and Kashmir (76, 95), Gujarat (88, 89, 96), Karnataka (74, 97-99), Madhya Pradesh (76), Himachal Pradesh (41), Punjab (100, 101), Tamilnadu (102, 103), Eastern Himalayas (40), Kerala (70), Maharashtra (39), Arid region, Rajasthan (65), Kolkata (43).

Cosmarium moniliforme Ralfs 1848: 107, pl. XVII [17]: Fig. 6.

Small cells, 17-19 $\mu \mathrm{m}$ long and 10-12 $\mu \mathrm{m}$ wide, 2-3 $\mu \mathrm{m}$ wide isthmus, semi cells circular in shape; cell wall finely punctate, little deep median constriction; widely 
open acute sinus; rounded apex; axial chloroplast with central pyrenoid (Fig. 4, c).

Collection no.: WUA 53, WUA 26 and WUA 41.

Ecological notes: In association with other phytoplanktons. $\mathrm{pH}$ 8, Temp.: $22^{\circ} \mathrm{C}$.

Indian distribution: East India (58), Andhra Pradesh (94), Madhya Pradesh (72, 86, 104), Maharashtra \& Karnataka (8, 74, 98), Uttar Pradesh (105), Kashmir (29), Central India (106), Uttar Pradesh (107, 108), Gujarat (109), Pithoragarh (110), Uttar Pradesh (111), Uttaranchal (112), Western Himalaya (40), Karnataka (113, 114), Chhattisgarh (115), Tamil Nadu (63), Assam (116), Eastern Himalaya (117), Kolhapur, Maharashtra (77), Kolkata (43).

Cosmarium nitidulum De Notaris 1867: 42, pl. III [3]: Fig. 26.

Cell small, little longer than broad, 24-28 $\mu \mathrm{m}$ long and $24 \mu \mathrm{m}$ wide, $8 \mu \mathrm{m}$ wide isthmus, constriction deep; narrowly linear sinus; apex is slightly dilated; truncate-sub semicircular semi cells, straight margin, rounded apex; punctate cell wall; axial chloroplast with one pyrenoid (Fig. 4, d).

Collection no.: WUA 06 and WUA 08.

Ecological notes: In association with mosses and green algae. pH 7.9, Temp. $19^{\circ} \mathrm{C}$.

Indian distribution: Andaman and Nicobar (28), Western Himalaya (40), Himachal Pradesh (41), Maharashtra (39, 71, 73, 77).

Cosmarium subtumidum Nordstedt in Wittrock, Nordstedt \& Lagerheim 1878: no. 172.

Cells are longer than broad having deep middle constriction, Cells are 18.7-25 $\mu \mathrm{m}$ long and 12-19.5 $\mu \mathrm{m}$ wide, 4-5 $\mu \mathrm{m}$ wide isthmus; nearly dilated apex with narrow linear sinus; pyramid-semicircular shape semi cells, rounded basal angles, convex lateral margin; axile chloroplast having single pyrenoid in each semi cell (Fig. 4, e).

Collection no.: WUA 06, WUA 18 and WUA 56.

Ecological notes: In association with other phytoplanktons. pH 7.7, Temp. $21^{\circ} \mathrm{C}$.

Indian distribution: Andhra Pradesh (118), Gujarat (119, 120), Ladakh (30), Maharashtra (39, 71), Kolkata (43).

\section{Cosmarium reniforme (Ralfs) W.Archer 1874: 92}

Cells medium sized, somewhat longer than broad, 32$35 \mu \mathrm{m}$ long and $33 \mu \mathrm{m}$ wide, $12 \mu \mathrm{m}$ wide isthmus; constriction deep, narrow to linear sinus with widely opened margin; reniform semi cells; granulate cell wall, granules fairly regular; axile chloroplast (Fig. 4, f).

\section{Collection no.: WUA 15, WUA 18, WUA 36 and WUA 24.}

Ecological notes: In association with green filamentous algae. $\mathrm{pH} 7.9$, Temp. $19{ }^{\circ} \mathrm{C}$.

Indian distribution: Jammu and Kashmir (121), Gujarat (119), Andaman \& Nicobar (28), Ladakh(30), Himachal Pradesh (41), Eastern Himalayas, Assam (69),
Karnataka (4), Rajasthan (64), Maharashtra (12, 39, 85).

Cosmarium undulatum Corda ex Ralfs 1848: 97, pl. XV [15]: Fig. 8.

Small cells with quadrate-elliptic shape, little longer than broad, $22.8 \mu \mathrm{m}$ long and $19 \mu \mathrm{m}$ wide, $3.5 \mu \mathrm{m}$ long isthmus; deep constriction; narrow sinus with dilated margin; sub-semicircular semi cell with 6-7 undulations; smooth cell wall; chloroplast axile having single pyrenoid in each semicell (Fig. 4, g).

Collection no.: WUA 29, WUA 15 and WUA 18.

Ecological notes: Attached with other wooly algae on pebbles. pH 8, Temp. $22^{\circ} \mathrm{C}$.

Indian distribution: Manipur (73), Maharashtra (71, 85).

Cosmarium obtusatum (Schmidle) Schmidle 1898: 38, pl. 2: Fig. 5, 6.

Cells medium sized, longer than broad, 50-57.4 $\mu \mathrm{m}$ long and 35.6-38.4 $\mu \mathrm{m}$ wide, $10.6 \mu \mathrm{m}$ wide isthmus; middle constriction; linear sinus with widely rounded lobes; smooth to slightly punctate cell wall; subsemicircular semi cell with small 15-17 undulations, poles slightly flattened; each semi cells with having two chloroplasts with single pyrenoid (Fig. 4, h).

Collection no.: WUA 13, WUA 29, WUA 07 and WUA 53.

Ecological notes: From the water squished from other algal samples. $\mathrm{pH} 7.9$, Temp. $19^{\circ} \mathrm{C}$.

Indian distribution: Jammu and Kashmir (121), Maharashtra (122), Madhya Pradesh (78), Nagpur (123), Ladakh (30).

Euastrum spinulosum Delponte 1876: 97, pl. VI [6]: Fig. 17, 18.

Cells small in size, longer than broad, 47-55.4 $\mu \mathrm{m}$ long and 30-35 $\mu \mathrm{m}$ wide, $18 \mu \mathrm{m}$ wide isthmus; deep constriction, narrow sinus widely rounded lobes; each semi cells with 5 lobed rounded angles, big granules and acute indentations between them. Cell wall with short spines, above the isthmus 2 small lateral protuberances are present (Fig. 4, i).

Collection no.: WUA 30, WUA 18 and WUA 24.

Ecological notes: In association with filamentous green algae. pH 7.8, Temp. $23^{\circ} \mathrm{C}$.

Indian distribution: Chhattisgarh (124), Andaman and Nicobar (28), Western Himalaya (40), Jharkhand (125), Maharashtra $(12,39,122)$, Gujarat $(96,119)$.

Euastrum platycerum Reinsch 1875: 85, pl. 12: Fig. 6.

Cells are of medium sized, longer than broader, 33-38 $\mu \mathrm{m}$ and 20-30 $\mu \mathrm{m}$ wide, isthmus $11 \mu \mathrm{m}$ wide; sinus slightly open; semi cell with circular patch of granules with low median protrusion, Lateral margins are broadly rounded (Fig. 4, j).

Collection no.: WUA 53, WUA 07 and WUA 41.

Ecological notes: Attached with other wooly algae on substrate. $\mathrm{pH} 7.9$, Temp. $19^{\circ} \mathrm{C}$. 
Indian distribution: Karnataka (126), Himachal Pradesh (41).

Staurastrum crenulatum (Nägeli) Delponte 1877: 68 [reprint p. 164], pl. 12: Fig. 1-11.

Cells 25-27 $\mu \mathrm{m}$ long and 10.9-12.3 $\mu \mathrm{m}$ wide with processes, 6.7-8.5 $\mu \mathrm{m}$ isthmus wide, short and slightly divergent processes, tipped processes 2-3 spine; crenate to denticulate cell wall; oval or sub-fusiform semi cells, shallow median constriction (Fig. 4, k).

Collection no.: WUA 57, WUA 18 and WUA 14.

Ecological notes: In association with other phytoplanktonic sample. pH 8, Temp. $22^{\circ} \mathrm{C}$.

Indian distribution: Goa (79), Maharashtra (75), Bhopal (68).

\section{Discussion}

Present study is a first report from the study area and deals with the diversity of desmid from the Ropar wetland of Punjab, India. In this study, taxonomic position of observed desmid species was investigated on the basis of their phenotypic features and their distribution in India was also determined, the detailed limnological study has not been carried out during this work. A total of 21 taxa of desmids have been recorded during present investigation, earlier only three genera like Closterium, Cosmarium and Penium were reported only at genus level from Punjab $(44,45$, 54). Thus, all the desmid taxa reported during this study are the first report from Ropar Wetland as well as from Punjab. Out of 21 taxa of desmids, fourteen taxa were belonging to family Desmidiaceae and seven taxa to family Closteriaceae. The genus Cosmarium exhibited high species diversity (11 species), followed by the genus Closterium (7 species) of the total diversity of study area. It has been observed that water of this wetland was slight alkaline (pH 7.7-8.0), which may cause low diversity of desmids in this wetland. According to previous reports $(117,127)$ the acidic condition of water favors more growth of desmids in comparison to alkaline water.

The comparison of observation of present study with other available reports from India (9, 12, 35-43) indicates low diversity of desmids in the study area. This may be due to different habitat nature and water quality conditions. As high desmid diversity has been observed from the wetlands habitat having abundant growth of macrophytes (128) and Sphagnum bog carpets (129). The desmid taxa, $C$. acerosum, $C$. dianae, C. moniliforme and E. platycerum were observed to be widely distributed in different water bodies of India $(9,12,35-43,128)$ and results of current study further advocate the cosmopolitan nature of distribution of these taxa. According to reports (130), C. acerosum is a high nutrient tolerant species which indicates the eutrophic nature of water. It was also reported that Closterium spp. were dominated in polluted water (131). From the results of present study, it is suggested that the continue bio-monitoring studies with holistic assessment of water quality conditions are required to develop strategies and water quality improvement programmes for this wetland.

\section{Conclusion}

In this study, the desmid flora of the Ropar wetland, Punjab (India) has been studied for the first time. All species recorded in this work are new records for study area as well as from Punjab. The habitat of this wetland does not support luxuriant growth of desmids due to alkaline nature of water. A high nutrient tolerant taxon i.e. C. acerosum has also observed during this study which may be the first indication towards the deterioration of water of this wetland. The present study provides more information about the biological diversification of this wetland and will be helpful in future for further limnological analysis.

\section{Acknowledgements}

Authors acknowledged the Vice-chancellor, Sri Guru Granth Sahib World University, Fatehgarh Sahib, Punjab and Head, Department of Botany, Punjabi University, Patiala for providing required research facilities.

\section{Authors' contributions}

YS and JISK provided conceptualization and resources, review and edited the manuscript. Komal investigated, analyzed data and wrote the initial draft of manuscript. YS and DPS reviewed and edited the manuscript. All authors have read and approved the manuscript for publication.

\section{Conflict of interests}

All authors declare no conflict of interest.

\section{References}

1. Bassi N, Kumar MD, Sharma A, Pardha-Saradhi P. Status of wetlands in India: a review of extent, ecosystem benefits, threats and management strategies. J Hydrol Reg Stud. 2014;2:119. https://doi.org/10.1016/j.ejrh.2014.07.001

2. Bianca Molinari, Ben Stewart-Koster, Maria Fernanda Adame, Max D. Campbell, Glenn McGregor, Cameron Schulz, Tim J. Malthus, Stuart Bunn. Relationships between algal primary productivity and environmental variables in tropical floodplain wetlands, Inland Waters. 2021. https://doi.org/10.1080/20442041.2020.1843932

3. Gopal B. Should 'wetlands' cover all aquatic ecosystems and do macrophytes make a difference to their ecosystem services? Folia Geobot. 2016;51:209-26. https://doi.org/10.1007/s12224-0169248-X

4. Wondie A. Ecological conditions and ecosystem services of wetlands in the Lake Tana Area, Ethiopia. Ecohydrol Hydrobiol. 2018;18:231-44. https://doi.org/10.1016/j.ecohyd.2018.02.002

5. Reis V, Hermoso V, Hamilton SK, Ward D, Fluet-Chouinard E, Lehner B, Linke S. A global assessment of inland wetland conservation status. Bioscience. 2017;67(6):523-33. https://doi.org/10.1093/biosci/bix045

6. Bobbink R, Whigham DF, Beltman B, Verhoeven JTA. Wetland Functioning in Relation to Biodiversity Conservation and Restoration. In: Bobbink R, Beltman B, Verhoeven JTA, Whigham DF (eds) Wetlands: Functioning, Biodiversity Conservation and Restoration. Ecological Studies (Analysis and Synthesis). 2006; vol 191. Springer, Berlin, Heidelberg. https://doi.org/10.1007/978-3-540-33189-6_1 
7. Dudgeon D, Arthington AH, Gessner MO, Kawabata ZI, Knowler DJ, Lévéque C, Naiman R J, Prieur Richard AH, Soto D, Stiassny MLJ, Sullivan CA. Freshwater biodiversity: Importance, threats, status and conservation challenges. Biol. Rev. 2006;81:163-82. http://dx.doi.org/10.1017/S1464793105006950

8. Reddy M, Chaturvedi A. Desmids from the rivers of Chandrapur district, Maharashtra. An Int J Environ Biodiv. 2017;8(1):25-34.

9. Ghule AV, Halwe DR. Desmid flora of Shaha lake, Karanja (Lad), Dist. Washim (M.S.). J. Grid Distrib. Comput. 2020;13(1s):22-28.

10. Aquino CAN, Medeiros G, Bortolini JC, Favaretto CCR, Ticiani D, Cerqueira JF, Bueno NC et al. Desmids (Zygnematophyceae) from the littoral zone of an urban artificial lake: taxonomic aspects and geographical distribution. Acta Limnol Bras. 2018, vol. 30, e202. https://doi.org/10.1590/s2179-975x4417

11. Hansen G, Stastny J, Moestrup $\emptyset$, Lundholm N. Diversity and conservation of desmids in Bornholm, Denmark-revisiting after 130 years. Nord J Bot. 2018. https://doi.org/10.1111/njb.0199

12. Valvi AB, Gautam PK. Studies on Some Desmids of Toranmal Reserve Forest of Satpura Ranges, Nandurbar District, Maharashtra, India. A J 2020;8(4):355-61.

13. Coesel PFM. A method for quantifying conservation value in lentic freshwater habitats using desmids as indicator organisms. Biodiv Conserv. 2001;10:177-87. https://doi.org/10.1023/A:1008985018197

14. Coesel PFM. Desmid floor data as a tool in conservation management of Dutch freshwater wetlands. Biologia, 2003;58:717-22.

15. González Garraza G, Burdman L, Mataloni G. Desmids (Zygnematophyceae, Streptophyta) community drivers and potential as a monitoring tool in South American peat bogs. Hydrobiologia. 2019;833:125-41. https://doi.org/10.1007/s10750 019-3895-x

16. Islam AKN, Md. Irfanulah H. Hydrobiological studies within the tea gardens at Srimangal, Bangladesh. Vi. Desmids (Xanthidium, Arthrodesmus, Staurodesmus and Staurastrum).Bangladesh Plant Taxon https://doi.org/10.3329/bjpt.v13i2.583 2006;13(2):111-29.

17. Coesel PFM, Krienitz L. Diversity and geographic distribution of desmids and coccoid green algae. Biodivers Conserv. 2008;17:381-92. http://dx.doi.org/10.1007/978-90-481-2801-3_11

18. Tomaszewicz GH, Hindák F. Some rare desmids (Zygnematophyceae) from Central Europe. Biologia. 2008;63 (3):289-93. https://doi.org/10.2478/s11756-008-0051-x

19. Rai SK, Misra PK. On some desmids from Koshi Tappu Wildlife Reserve, Nepal. $\quad$ Ecoprint. 2008;15:47-58. https://doi.org/10.3126/eco.v15i0.1942

20. Rai SK, Rai RK, Paudel N. Desmids from Bees-hazaar Lake, Chitwan, Nepal. Our Nature. 2009;6:58-66. https://doi.org/10.3126/on.v6i1.1656

21. Geest AV, Coesel P. Desmids from Lake Nabugabo (Uganda) and adjacent peat bogs. Fottea. 2012;12(1):95-110. http://dx.doi.org/10.5507/fot.2012.008

22. da Silva FKL, Felisberto SA. Euastrum and Micrasterias (family Desmidiaceae) in lentic tropical ecosystem, Brazil. Biota Neotrop. 2015;15(1):1-12. http://dx.doi.org/10.1590/167606032015007914

23. Briškaitè R, Pateva E, Juzènas S. Desmid flora in the lakes of the Khrebtovyi nature reserve in the Polar Ural (Russia). Bot. Lith. 2016;22(2):113-22. http://dx.doi.org/10.1515/botlit-2016-0012

24. Sahin B, Akar B. New desmid records from high mountain lakes in Artabel Lakes Nature Park, Gümüşhane, Turkey. Turk J Botany. 2019;43:570-83. https://doi.org/10.3906/bot-1810-71

25. Shakhmatov AS, Pavlovskiy EV. Diversity of desmid algae (Charophyta: Conjugatophyceae) in the vicinity of Yugorsk city (KMAO-Yugra, Russia). Folia Cryptogam. Estonica Fasc. 2019;56:11-22. https://doi.org/10.12697/fce.2019.56.03

26. Aquino, CAN, Medeiros G, Bortolini JC, Favaretto CCR, Ticiani D, Cerqueira FJ, Bueno NC. Desmids (Zygnematophyceae) from the littoral zone of an urban artificial lake: taxonomic aspects and geographical distribution. Acta Limnol Bras. 2018;30:202. https://doi.org/10.1590/S2179-975X4417
27. Shakhmatov AS. Genera Euastrum and Micrasterias (Charophyta, Desmidiales) from fens in the southern part of middle Urals, Russia. Botanica. 2020;26(1):15-27. https://doi.org/ 10.2478/botlit-2020-0002

28. Prasad BN, Misra PK. Monograph on fresh water algal flora of Andaman and Nicobar Islands. Bishen Singh Mahendra Pal Singh, Dehradun 1992;2:284.

29. Compére P. Some algae from Kashmir \& Ladakh, W. Himalayas Bull Soc R Bot Belge. 1983;116:141-60.

30. Kant S, Gupta P. Algal flora of Ladakh. J Econ Taxon Bot. 1998;1 341.

31. Lakshminarayana JSS. Algal flora of Uttar Pradesh IV. Chlorophyceae: Conjugales, Siphonales and Charales. Environ Health 1963;5:1-5.

32. Hegde GR. Some noteworthy Desmids from Londa, Karnataka State (India). Hydrobiologia. 1986;134:113-15. https://doi.org/10.1007/BF00006734

33. Hegde GR. New records of desmids from Karnataka state-I. Phykos. 1986;25:117-22.

34. Divekar MV, Pingle SD, Deshmukh BS. Algal biodiversity of dairy waste water in Sangamner area (Maharashtra). Proc Nat Conf Plant Sci. Pravaranagar. 2005;261264 p.

35. Mahajan SR, Nandan SN. Green algae of Hartala lake of Jalgaon, Maharashtra. Pro Nat Symp Rec. Trends Algal Biotech Biodiv. 2007:51-54.

36. Kumawat DA, Jawale AK, Bhoge ON, Narkhede PN, Patil SS Algae from Household Waste of Faizpur, Dist. Jalgaon, Maharashtra. Proc Nat Symp Rec Trends Algal Biotech Biodiv. 2007:86-90.

37. Mahajan SR. Diversity of desmids at Jalgaon, North Maharashtra. Bioinfolet. 2011;8(1):37.

38. Patil SA, Jawale AK. Desmids from Mangrul dam, Dist. Jalgaon, Maharashtra. Int J Geol Earth Environ Sci. 2014;4(1):137-46.

39. Patil SB, Kumawat DA. Diversity of genus Cosmarium corda from Abhora dam of Jalgaon district, Maharashtra. Int J Geol Earth Environ Sci. 2015;4(1):109-14.

40. Shukla SK, Shukla CP, Misra PK. Desmids (Chlorophyceae, Conjugales, Desmidiaceae) from Foothills of Western Himalaya India. Algae. https://doi.org/10.4490/ALGAE.2008.23.1.001

41. Dwivedi RK, Shukla CP, Misra PK, Shukla SK, Seth MK. On Desmids of Southern Himachal Pradesh of Indo-Western Himalaya. Feddes Report 2009;120(3\&4):236-49. http://dx.doi.org/10.1002/fedr.200911106

42. Das D, Keshri JP. Desmids from Manmecho (Mamencho) Lake, Eastern Himalaya. I. NeBio. 2012a;3(2):37-44

43. Nandi C, Bhowmick S, Gorain PC, Pal R. New and Rare Records of Cosmarium (Desmidiaceae, Zygnematales) from India. Phytomorphology. 2019;69(1\& 2):41-49.

44. Brraich OS, Kaur R. Phytoplankton community structure and species diversity of Nangal Wetland, Punjab, India. Int Res J Biological Sci. 2015;4(3):76-83.

45. Brraich OS, Saini SK. Phytoplankton abundance and species diversity in Ranjit Sagar Wetland, Punjab (India). Curr World Environ. 2015;10(1):215-21. https://doi.org/10.12944/CWE.10.1.25

46. Dhingra R. Biodiversity assessment and conservation of blue green algae from Punjab. PhD thesis. Department of Botany, Panjab University, Chandigarh. 2006241 pp.

47. Singh DP, Khattar JIS, Ahuja G, Singh Y. Cyanobacterial diversity in rice fields of Malwa region of Punjab and their tolerance to Chlorpyrifos. J Punjab Acad Sci. 2007;4(1\&2):106-13.

48. Singh DP, Khattar JIS, Singh Y. Effect of pesticides on the distribution pattern of cyanobacteria in a rice field ecosystem. Indian J Bot. 2009;88(1\&2):163-69.

49. Sharma C, Jindal R, Singh UB, Ahluwalia AS, Thakur RK Population dynamics and species diversity of plankton in relation to hydrobiological characteristics of river Sutlej, Punjab, India. Ecol Environ Conserv. 2013;19 (3):717-24.

50. Ramsar. 2002. https://rsis.ramsar.org/ris/1161 
51. Ladhar SS. Status of ecological health of wetlands in Punjab, India. Aquat Ecosyst Health Manag. 2002;5(4):457-65. https://doi.org/10.1080/14634980290002002

52. Brraich OS, Akhter S. Diversity and distribution of zooplankton in Ropar Wetland (Ramsar Site) Punjab, India. Nat Environ Pollut Technol. 2019;18(2):451-58.

53. Ladhar SS. Ropar wetland. Chandigarh: Punjab State Council for Science and Technology. 2005;1-64.

54. Akhter S, Brraich OS. Physico-chemical analysis of fresh water of Ropar wetland (Ramsar site), India. Curr World Environ. 2020;15(1):117-26. http://dx.doi.org/10.12944/CWE.15.1.15

55. Ralfs J. The British Desmidieae: 226. Reeve, Benham \& Reeve, London;1848.

56. West W. Algae of the English lake district. J Roy Microscop Soc 1892;8:713-48. https://doi.org/10.1111/j.1365-2818.1892.tb05529.x

57. Turner WB. The fresh-water algae (principally Desmidiaceae) of East India. K Sven Vetensk Akad Handl. 1892;25:1-187.

58. Hughes EO. Closterium in Central Canada. Canadian J Bot. 1952;30:266-89. https://doi.org/10.1139/b52-020

59. Prescott GW, Croasdale HT, Vinyard WC. Desmidiales Part I. North American Flora, 1972;Series II, Part I:1-84. The New York Botanical Garden, New York.

60. Prescott GW, Croasdale HT, Vinyard WC. A synopsis of North American desmids Part II. Desmidiaceae: Placodermae Section 1, 1975:1-275. University of Nebraska Press, USA.

61. Guiry MD, Guiry GM. AlgaeBase. World-wide electronic publication. Galway, National University of Ireland. http://www.algaebase.org (Accessed at 20 November 2020).

62. Tessy PP, Sreekumar R. A report on the pollution algae from the Thrissur Kol wetlands (part of vembanad Kol, Ramsar site), Kerala. Nat Environ Pollut Technol. 2008;7(2):311-14.

63. Singh RP, Balasingh GSR. Contribution of algal flora in kodaikanal lake, dindigul district, Tamilnadu. Ind J Fund App Life Sci. 2012;2(4):134-40.

64. Barupal, G. K. \& Narayan, P. 2016: Chlorophycean flora of Kaylana Lake, Jodhpur (Rajasthan), India. J Algal Biomass Util. 7 (1):1-11.

65. Barupal GK. Algal biodiversity of the arid region of Rajasthan. Algal Biomass Util. 2019;10(1):26-35.

66. Raut L, Bhardwaj AK. A study of Closterium in Tapti pond of Multai, district Betul, M.P. India Int J Botany Stud. 2017;2 (5):118-20.

67. Jena M, Adhikary SP. Algal diversity of Loktak lake, Manipur. Nelumbo. 2011;53:21-48.

68. Bhat NA, Wanganeo A, Raina R. Variability in water quality and phytoplankton community during dry and wet periods in the tropical wetland, Bhopal, India. J E E. 2015;5(2):1-8. http://dx.doi.org/10.4172/2157-7625.1000160

69. Yasmin F, Buragohain BB, Medhi KK. Planktonic Desmid flora of south of the Eastern Himalayas: A systematic approach on algae-I. Int J Botany. http://dx.doi.org/10.3923/ijb.2011.154.161

70. Vijayan D, Ray JG. Ecology and diversity of cyanobacteria in Kuttanadu paddy wetlands, Kerala, India. Am J Plant Sci. 2015. http://dx.doi.org/10.4236/AJPS.2015.618288

71. Kamat ND. Algae of Vidarbh, Maharashtra. Bombay Nat Hist Soc. $1975 ; 72: 450-76$

72. Agarkar DS, Agarker MS. Contribution to the desmids of Madhya Pradesh, India (Desmids from Vidhyan Region). Port. Acta Biol. 1973;12:159-78.

73. Bruhl P, Biswas K. Algae of the Loktak Lake. Mem Asiat Soc Bengal. 1926;8:257-316.

74. Kiran BR. Distribution and occurrence of desmids in bhadra reservoir, Karnataka. Int J Res Environ Sci. 2016;2(3):1623.http://dx.doi.org/10.20431/2454-9444.0203002

75. Gonzalves EA, Joshi DB. Fresh water algae near Bombay I. The seasonal successions of algae in a tank of Bandra. Bombay Nat Hist Soc. 1946;46(1):154-76.
76. Paul Y, Anand VK. Unicellular and colonial Chlorophycean algal taxa from Jammu and adjoining areas. J Plant Dev. 2009;1(34):99-104.

77. Karande CT, Khade SK, Joshi H. An account of desmid diversity from Kolhapur district (Maharashtra), India. I J S R R. 2018;7(3):1779-85.

78. Agarkar DS. Contribution to the desmids of Gwalior, Madhya Pradesh (India)-II. Phykos. 1971:10(1-2):54-69.

79. Bharati SG, Hedge GR. The genera Staurstrum Meyen and Staurodesmus Teil. (Desmidiaceae) in Karnataka and Goa States (India). Hydrobiologia. 1982;96:31-51. https://doi.org/10.1007/BF00006277

80. Bharati SG, Hedge GR. Desmids of Karnataka state and Goa. Part 1. Phykos. 1982;21:143-49.

81. Patel RJ., Ashok Kumar CK. Desmids of Gujarat, India l. Genus Closterium Nitzsch. Phykos. 1979;18:111-24.

82. Ajayan AP, Kumar AKG. Micro algal diversity of the lake inside the government zoological garden, Thiruvananthapuram, Kerala India. Int J Environ Sci. 2015;6(3):330-37. http://dx.doi.org/10.6088/ijes.6037

83. Das SK, Maurya ON. Floristic survey of Algae in Vikramsila Gangetic Dolphin Sanctuary, Bihar (India). Nelumbo. 2015 57:124-37. https://doi.org/10.20324/nelumbo/v57/2015/87116

84. Ashtekar PV, Kamat ND. Additions to the desmid flora of Marathwada, Maharashtra. Phykos. 1978;18(1\&2):45-50.

85. Mhaske TK, Talwankar DS. Occurrence of Cosmarium species in Khadakpurna reservoir, Buldana district - Maharashtra, India. GSC Biol Pharm Sci. 2018;05(03):020-024. https://doi.org/10.30574/gscbps.2018.5.3.0136

86. Agarkar DS. Contribution to the desmids of Gwalior, Madhya Pradesh, (India). Phykos. 1969;8(1\&2):01-10.

87. Shaji C, Jose L, Patel RJ. Addition of Desmid Flora of Kerala Phykos. 1988;27:32-37.

88. Ashokakumar CK, Patel RJ. Desmids of Gujarat- Genus Cosmarium Corda. Phykos. 1988;27:117-28.

89. Dhande JS, Jawale AK. Genus Cosmarium corda from Hartala Lake district Jalgaon, Maharashtra. S S M. 2009;2:196-98.

90. Kamat ND. The algae of Mahabaleshwar. J U B. 1963;31(3\&5):28 41.

91. Ashtekar PV, Kamat ND. Additions to the desmid flora of Marathwada, Maharashtra. Phykos. 1979;18:45-50.

92. Suxena PN. Algae flora of user lands in Uttar Pradesh. Sci Cult. 1960;25 (9):542-43.

93. Carter N. Fresh water algae from India. Rec Bot Surv India 1926;9(4):263-302.

94. Suxena MR, Venkateswarlu V. Desmids from Andhra Pradesh, from Pakhal Lake, Warangal. Hydrobiologia. 1968;28:49-65. https://doi.org/10.1007/BF00144938

95. Kamat ND. Chlorophyceae of Ahmadabad, India. Hydrobiologia. 1962;20:248-79. https://doi.org/10.1007/BF00046193

96. Kumar RN, Solanki R, Kumar NJI. Spatial variation in Phytoplankton diversity in the Sabarmati river at Ahmedabad, Gujarat, India. Annals Environ Sci. 2012;6:13-28.

97. Jayangoudar I. A bio-ecological study of Nuggikari Lake in Mysore State, South India. Hydrobiologia. 1964;23:515-32. https://doi.org/10.1007/BF00179500

98. Bharati SG. A systematic survey of the desmids of the BombayKarnataka, part II. J Karnataka Univ Sci. 1966;11:174-82.

99. Somashekhar RK. Contribution to the algal flora of river Kapila, Karnataka I. Cyanophyceae and Chlorophyceae. Phykos. 1984;23(1\&2):116-24.

100. Singh M. Planktonic algae from Najafgrah Lake-II. Res Bull Pun Univ Sci. 1966;17:99-103

101. Singh M. A list of planktonic green algae from Amritsar, Punjab. J Bombay Nat Hist Soc. 1966;63(1):74-83.

102. Mahendraperumal G, Anand N. Biodiversity of fresh water algae in Tamilnadu II, Biology and Biodiversity of Microalgae. 
Centre for Advanced Studies in Botany, University of Madras 2009:302-08

103. Mayakkannam G, Maya. The biology and Biodiversity of Microalgae of forest soils and Subaerial habitats of Tamil Nadu. Ph.D. Thesis, University of Madras; 2010.

104. Agarker MS, Agarkar DS, Desmids from Pachmarhi, Madhya Pradesh, India. Hydrobiologia. 1977;54:23-32. https://doi.org/10.1007/BF00018768

105. Prasad BN, Mehrotra RK. Desmid flora of North Indian paddy fields. New Botanist. 1977;4(1-4):49-74.

106. Unni KS. Comparative limnology of several reservoirs in central India. Int Rev Hydrobiol. 1985;70:845-56. https://doi.org/10.1002/iroh.19850700610

107. Pandey UC, Habib I. Desmids of Bareilly-I. J Indian Bot Soc. 1987;66:291-96.

108. Habib I, Chaturvedi UK. Contribution to the desmids of Rohilkhand division. Phykos. 1993;32:51-54.

109. Kumar ACK, Patel RJ. Desmids of Gujarat-I Genus Cosmarium Corda. Phykos. 1990;29:95-101.

110. Chaturvedi UK, Habib I. Algal flora of Pithoragarh. Phykos. 1993;32:55-56.

111. Habib I. Contribution to the desmids of Rohilkhand Division, U.P., India. Geophytol 1993;23(1):177-79.

112. Khere R, Suseela MR. Freshwater algal flora from four sites of Uttaranchal. J Econ Taxon Bot. 2007;374-79.

113. Shekhar TRS, Kiran BR, Puttaiah ET, Shivaraj Y, Mahadevan KM. Phytoplankton as index of water quality with reference to industrial pollution. J Environ Biol. 2008;29:233-36.

114. Giriayappanavar BS, Patil RR. Water quality assessment of For lake, Belgaum and Wadral lake, Wadral (Karnataka) with special reference to phytoplanktons. Lake. 2010;7:1-6.

115. Toppo K, Suseela MR. Cosmarium diversity of Mani Pokhar pond of Jashpur district in Chhattisgarh state. India. Ann For Sci. 2009;17:117-24.

116. Deka SJ, Sarma GC, Deka SP. Preliminary Checklist of desmids of Urpad Beel (Wetland) Goalpara District, Assam, India. Asian Exp Biol Sci. 2011;2(3):391-98.

117. Das D, Keshri JP. Desmids of Khechiperi Lake, Sikkim Eastern Himalaya. $\quad$ Algol Stud. $2013 ; 143: 27-42$. http://dx.doi.org/10.1127/1864-1318/2013/0136

118. Suxena MR, Venkateswarlu V. Desmids of Andhra Pradesh - IV, from Dharmasagar lake, Waranjal -2. J Osm Univ. (Sci.), Golden Jubilee Special Volume 1968;179-201.

119. Patel RJ. On Desmids of Gujarat. Bombay Nat Hist Soc. 1969;66:665-69.

120. Asokakumar CK, Patel RJ. Desmids of Gujarat - I. Genus Cosmarium Corda. Phykos. 1990;29: 95-101.
121. Suxena MR, Venkateswarulu V. Desmids from Kashmir. Phykos 1968;7(1-2):165-85

122. Kamat ND. Algae of Alibagh, Maharashtra. Bombay Nat Hist Soc 1968;65(1):88-104.

123. Freitas JF, Kamat ND. Desmidiaceae of Nagpur. Phykos. 1978;18(1\&2):97-103.

124. Roy M, Sen N. Fresh water algae of Chhattisgarh. Phykos. 1985;24:76-79.

125. Kumar A, Sahu R. Diversity of algae (Cholorophyceae) in paddy fields of Lalgutwa area, Ranchi, Jharkhand. J Appl Pharm Sci. 2012;2(11):92-95. http://dx.doi.org/10.7324/JAPS.2012.21116

126. Gurudeva MR, Arekal GD, Somashekar RK. Desmid flora of Savandurga, Karnataka. Phykos. 1983;22:48-56.

127. Brook AJ. The biology of desmids. Blackwell Scientific Publication, Oxford 1981., pp 276.

128. Ngearapat N, Peerapornpisal Y. Application of desmid diversity in assessing the water quality of 12 freshwater resources in Thailand. J Applied Phycol. 2007;19:667-74. https://doi.org/10.1007/s10811-007-9191-6

129. Mazalová P, Štěpánková J, Poulíčková A. Desmid flora of mires in Central and Northern Moravia (CzechRepublic). Čas Slez Muz. Opava (A) 2013;62:1-22. https://doi.org/10.2478/cszma-2013-0001

130. Palmer CM. A composite rating of algae tolerating organic pollution. J Phycol. 1969;5(1):78-82. https://doi.org/10.1111/j.1529-8817.1969.tb02581.x

131. Stamenković M, Cvijan M. Desmid flora (Chlorophyta, Zygnematophyceae) of the Danube in the Province of Vojvodina (Northern Serbia). Arch Biol Sci Belg. 2008;60(2):181-99. https://doi.org/10.2298/ABS0802181S

Additional information

Peer review information: Plant Science Today thanks Sectional Editor and the other anonymous reviewers for their contribution to the peer review of this work.

Reprints and permissions information is available at https://horizonepublishing.com/journals/index.php/PST/open_access_policy

Publisher's Note: Horizon e-Publishing Group remains neutral with regard to jurisdictional claims in published maps and institutional affiliations.

To cite this article: Komal, Khattar J.I.S, Singh D.P, Singh Y. New records of desmids from Ropar wetland (a Ramsar Site) of Punjab, India. Plant Science Today. 2021;8(4):1037-1048. https://doi.org/10.14719/pst.2021.8.4.1229

Plant Science Today, published by Horizon e-Publishing Group, is covered by Scopus, Web of Science, BIOSIS Previews, Clarivate Analytics, etc. See https://horizonepublishing.com/journals/index.php/PST/indexing_abstracting 